\title{
Comparative Economics of Rice-Ratoon-Green gram Production System in East and South East Coastal Plain Zone of Odisha, India
}

\author{
Sanat Kumar Dwibedi ${ }^{1 *}$, Gopal Chandra De ${ }^{2}$, Sudhi Ranjan Dhua ${ }^{3}$, \\ Biswa Ranjan Pattanaik ${ }^{1}$, Bijaya Kumar Sethy ${ }^{1}$ and Sasmita Priyadarshini ${ }^{1}$ \\ ${ }^{1}$ Orissa University of Agriculture and Technology, Bhubaneswar, Odisha, India \\ ${ }^{2}$ ASEPAN, Sriniketan, Visva Bharati, Bolpur, West, Bengal, India \\ ${ }^{3}$ CID, National Rice Research Institute, Cuttack, Odisha, India \\ *Corresponding author
}

\begin{tabular}{l} 
K e y w o r d s \\
$\begin{array}{l}\text { Modifies system of rice } \\
\text { intensification, Best } \\
\text { management practice, } \\
\text { Ratoon, Green gram, } \\
\text { Production economics }\end{array}$ \\
\hline Article Info \\
$\begin{array}{l}\text { Accepted: } \\
\text { 20 January } 2018 \\
\text { Available Online: } \\
\text { 10 February } 2018\end{array}$ \\
\hline
\end{tabular}

Early sowing of rice by 20 June produced significantly the highest grain yield followed by normal (5 July) and late sowings (20 July) and the yield of its stubble crop also followed the similar trend. The combined grain yields of early sown rice-ratoon and the rice equivalent yield (REY) of early sown green gram was significantly higher by $8.64 \%$ and $23.74 \%$ than normal and late sowings, respectively in rice-ratoon-green gram system. The combined REY in modified system of rice intensification (MSRI)-ratoon-green gram system was $7.33 \%$ and $33.22 \%$ higher than system of rice intensification (SRI)-ratoongreen gram and best management practice (BMP)-ratoon-green gram system, respectively. The system with hybrid rice Ajay had significantly higher REY than the system with high yielding rice $\mathrm{cv}$. Tapaswini. The system productivity under early sowing of rice and green gram was significantly higher by $8.64 \%$ and $23.76 \%$ than normal and late sowings of such crops. To get maximum dividend in terms of net return, benefit-cost ratio and system profitability with minimum cost of production, early sowing of hybrid Ajay under MSRI followed by its ratoon and early sown green gram in sequence should be given first priority in east and south east coastal plain zone of Odisha, India having dwindling hybrid rice area.

\section{Introduction}

In India, rice occupies about 44.6 million hectares (Mha) with an annual production of about 86 million tonnes (Mt) and it continues to hold the key to sustain food production by contributing to $20-25 \%$ of agricultural gross domestic product (GDP) and assures food security for more than half of the total population (Balamurugan and Sudhakar,
2012). A set of water-saving rice cultivation management practices popularly known as 'System of Rice Intensification (SRI)' has been introduced from Madagascar to many countries including India. Planting young seedlings singly in wider square geometry, use of organics, alternate wetting and drying instead of flooding and mechanical weeding as followed in SRI compared with the continuous flooded traditional farmers' practices are well 
established in rice growing countries including India (Choudhury et al., 2007; Sato and Uphoff, 2007; Shekhar et al., 2009; Chapagain et al., 2011; Krupnik et al., 2012; Dass et al., 2012; Kumar and Singh, 2013; Dwibedi et al., 2016a; Dwibedi et al., 2016b), but research findings on the relative production efficiencies of subsequent ratoon or stubble crop of rice genotypes involving the recommended 'Best Management Practices (BMP)', SRI and 'Modified SRI (MSRI)' under assured irrigation system needed careful evaluation. MSRI is the system of growing rice as in SRI with similar nursery, nutrient, water, weed and pest management practices but with the plant geometry and seedling numbers per hill like in BMP. Earlier efforts have been made to assess the profitability of SRI compared to continuous flooded $\mathrm{BMP} /$ farmers' practice in rice crop only. But, the studies on the economics of rice-ratoon-green gram as influenced by time of sowing of rice and green gram and, systems of cultivation and genotypes of rice are still lacking.

The Department of Agriculture in the state of Odisha had promoted SRI in 21,000 ha during 2014-15 (Outcome Budget 2015-16, Agriculture Department, Government of Odisha). In coastal irrigated Odisha, summer crops are sometimes harvested late in May or June, which restricts the farmers for timely preparation of land for Kharif rice. Ultimately, the farmers are oriented towards delayed planting in more than 60 per cent of rice area. Moreover, as early period may leave the field in swampy condition which compels the farmers to keep the field fallow for a month or two, planting is also very often delayed keeping in view the suitability of plot for its preparation for the subsequent crop of green gram, However, no such work has yet been undertaken to study the relative performance of delayed planting under SRI and BMP in coastal plains. So also studies on the feasibility of a third crop of ratoon rice by utilizing the gap period between rice and green gram effectively and efficiently was still awaited.

Hence, efforts have been made here to elucidate the production economics of riceratoon-green gram cropping system under varying dates of sowing and water saving approaches.

\section{Materials and Methods}

\section{Experimental site}

The field experiments were conducted from 2009 to 2011 in the village Nimakana of Tirtol block, Jagatsinghpur district in east and south east coastal plain zone of Odisha, India at 25.6 $\mathrm{km}$ air distance from the Bay of Bengal at east. The experiment site in particular was located at $86^{\circ} 22^{\prime}$ E longitude, $20^{\circ} 17^{\prime} \mathrm{N}$ latitude and $14.0 \mathrm{~m}$ above the mean sea level. The experimental soil was clay loam in texture, moderately acidic in reaction $(\mathrm{pH} 5.6$ to 5.5$)$, high in soil organic carbon ( 0.79 to 0.87 ) and electrical conductivity (0.96 to 0.98 $\mathrm{ds} \mathrm{m}^{-1}$ ) so also the available primary plant nutrients were medium in $\mathrm{N}, \mathrm{P}_{2} \mathrm{O}_{5}$ (Bray, 1945) and $\mathrm{K}_{2} \mathrm{O}$.

\section{Climate and weather parameters}

The climate of the experimental location is characterized as "warm and moist" with a hot and humid summer and normal cold winter which broadly falls in the 'moist hot' group (Lenka, 1976). The range of maximum and minimum temperatures during the experimental cropping years was more or less similar as the long term average. The mean annual rainfall is $1,333.9 \mathrm{~mm}$ and nearly $62 \%$ of rainfall was being received between June and October $(827 \mathrm{~mm})$. The monsoon usually sets in around mid June and recedes by first week of October. July and August are wettest months, while December is the driest one. The 
daily mean sunshine hours during the period of investigation was more or less the same with the long term average and ranged from 1.82 to 7.84 hours. The crops enjoyed 5.57, 5.53 and 6.03 hours of average daily bright light during the first, second and third years, respectively. The total annual rainfall received during the period of investigation was within the range of normal $(-16.37 \%$ to $-9.89 \%)$ of the long term average $(1,333.9 \mathrm{~mm})$. The irrigation water requirements of rice and ratoon as depicted in the Table 1 varied due to difference in the sowing date and systems of cultivation. However, in green gram irrigation water of $1,500 \mathrm{~m}^{3} \mathrm{ha}^{-1}$ was applied during crop growth.

\section{Experimental design and treatments}

The treatments consisted of three dates of sowing $\left(\mathrm{D}_{1}, \mathrm{D}_{2}\right.$ and $\left.\mathrm{D}_{3}\right)$, three systems of cultivation $\left(S_{1}, S_{2}\right.$ and $\left.S_{3}\right)$ and two medium duration rice genotypes $\left(G_{1}\right.$ and $\left.G_{2}\right)$. Three dates of sowing were $\mathrm{D}_{1}-20$ June (rice)/ 2 January (green gram), $\mathrm{D}_{2}-5$ July (rice)/ 17 January (green gram) and $\mathrm{D}_{3}$ - 20 July (rice)/ 1 February (green gram). Three systems of cultivation of rice-ratoon-green gram were BMP-ratoon-green gram $\left(\mathrm{S}_{1}\right)$, SRI-ratoongreen gram $\left(\mathrm{S}_{2}\right)$ and MSRI-ratoon-green gram $\left(\mathrm{S}_{3}\right)$. Two medium duration rice genotypes released from National Rice Research Institute, Cuttack were $\mathrm{G}_{1}$-high yielding variety (HYV) 'Tapaswini' (IET 12168) and $\mathrm{G}_{2}$-hybrid 'Ajay' (CRHR-7, IET 18166). The experiment was carried out in a split-split plot design with 18 treatment combinations, replicated thrice. The first treatment involving three dates of sowing were assigned to the main plots. The second treatment of three systems of cultivation was allotted to three sub-plots and the two rice genotypes were grown in sub sub-plots. The treatments were allotted at random by the help of two digit random number table (Cochran and Cox, 1977). The subsequent mung bean (green gram) crop was grown with HYV Samrat (PDM-139), released in 2001 from the Indian Institute Pulses Research, Kanpur.

\section{Agronomic practices of ratoon rice}

Immediate after harvesting of plant rice at 10 $\mathrm{cm}$ above ground surface (Oad and Cruz, 2002) so as to facilitate ratooning through retillering process (Mobasser et al., 2009 and Daliri et al., 2009) the nitrogenous fertilizer at the rate of $60 \mathrm{~kg} \mathrm{ha}^{-1}$ was applied to the sub sub-plots. Subsequently, the field was irrigated for suppressing the fallen seeds from sprouting and acting as weeds. After retillering, sufficient water was maintained in the field to control weeds. As the maturity in ratoon rice was irregular, the field was drained out at $80 \%$ maturity stage and crop was then harvested leaving the residue at $5 \mathrm{~cm}$ above the ground level (Table 2).

\section{Agronomic practices of green gram crop}

After harvesting of the ratoon rice crop, the field was ploughed thoroughly and deeply and cross ploughed according to dates of sowing of green gram at 15 days intervals i.e. 2 January, 17 January and 1 February each year. Green gram seeds of cv. Samrat (PDM 139) after seed treatment with Vitavax power at the rate $1.5 \mathrm{~g} \mathrm{~kg}^{-1}$ were sown at $5 \mathrm{~cm}$ deep furrows and in paired rows with $15 \mathrm{~cm}$ intra paired row spacing and $35 \mathrm{~cm}$ inter paired row spacing. The crop was grown with residual soil fertility to study the effect of each treatment combination on the growth and yield attributes of the third crop of green gram after preceding plant and ratoon rice crops. However, the seeds were inoculated with strains of Rhizobium sps and $\mathrm{P}$ solublising bacteria (PSB) each at the rate of $20 \mathrm{~g} \mathrm{~kg}^{-1}$ of seeds just before sowing. The plots were irrigated with $5 \mathrm{~cm}$ depth of water just after sowing for early and uniform germination of the seeds. The weeds thus emerged were 
effectively managed with pre-emergence application of herbicide like Pendimethalin at the rate of $0.5 \mathrm{~kg}$ a.i. ha ${ }^{-1}$. Subsequently, two irrigations were applied at 20 and 40 DAS for mitigating the water requirement of green gram crop. The plants were thinned in the rows leaving 10 vigorous plants per running meter $(\mathrm{m})$ or 40 plants $\mathrm{m}^{-2}$ at about two weeks stage. Earthing up was carried out at 20 DAS and weeds remaining after herbicide application were thus incorporated. The crops were well protected from the attack of insectpests like white fly by using yellow sticky traps at the rate of 50 traps $\mathrm{ha}^{-1}$. That apart, neem oil at the rate of $5 \mathrm{~mL} \mathrm{~L}^{-1}$ of water was sprayed as prophylactic measures. Harvesting dates ranged from the month of March to April for the crop under different sowing dates of the green gram. The matured pods were plucked manually from the plants in net plot area for recording the economic yield plotwise. The pods were sun-dried for 3-4 days and threshed manually. The seed and haulm yield were recorded plot-wise after reduction of moisture content to $8 \%$.

\section{Methods of recording observations}

\section{Rice equivalent yield (REY)}

The yield from different crop components in the rice-ratoon-green gram cropping system was calculated in a single commodity term i.e. rice grain. Yields and prices of all the component crops were considered to determine the equivalency in yield.

Yields and prices of economic part like grains of both plant and ratoon rice and seeds of green gram were taken into consideration for evaluation. The equivalent yield was calculated using the following formula.

$$
\mathrm{REY}=\frac{\mathrm{Y}(\mathrm{g}) \cdot \mathrm{P}(\mathrm{g})}{\mathrm{P}(\mathrm{r})}
$$

Where,

REY denotes rice equivalent yield

$\mathrm{Y}(\mathrm{g})=$ Yield of green gram seeds

$\mathrm{P}(\mathrm{g})=$ Price of green gram seeds

$\mathrm{P}(\mathrm{r})=$ Price of rice grains

\section{Economics}

Independent calculations on the economics of production of different crops in all the three systems were carried out to analyse and interpreted the experimental output with their financial implications.

\section{Cost of cultivation}

The cost of cultivation of plant rice, ratoon rice and green gram taking account all the expenditure incurred in purchase of physical inputs like seeds, plant protection chemicals, nutrients, etc. and labour charges like bullocks, human and farm machineries, etc. were meticulously calculated as per prevailing market price in the locality and noted down for interpretation. The gross and net profit/ return from grains or seeds and straw were calculated as per the minimum support price for sale in the locality.

\section{Benefit-cost ratio (BCR)}

BCR was calculated by dividing gross return by the cost of cultivation in economist point of view. Higher or wider the ratio, more benefit or return on investment was reflected thereby.

\section{Cost of production (COP)}

The COP of individual crop was calculated by dividing the total cost incurred in cultivation of that crop by the grain yield of respective crop. It is expressed in term of Rs. $\mathrm{t}^{-1}$.

Lower the cost of production of any crop better is its adoptability and vice versa. 


\section{Crop profitability and system profitability}

The crop profitability was calculated by dividing the net return $\mathrm{ha}^{-1}$ by number of days (d) the field was occupied with that crop. Similarly, it was calculated by dividing the net return $\mathrm{ha}^{-1}$ year $^{-1}$ by 365 days. The crops and systems with higher profitability were economical and advisable. For calculating the profitability the pre-requisites viz. crop wise cost of cultivation, sale price of produce, gross return and duration of crop were required.

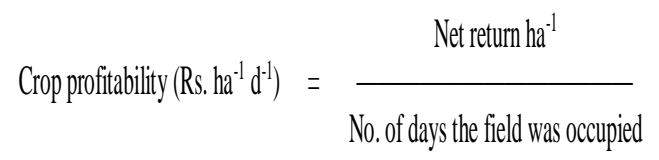

System profitability (Rs. ha $\left.{ }^{-1} d^{-1}\right)=\frac{\text { Net return ha }^{-1} \text { year }^{-1}}{365}$

\section{Statistical analysis}

The entire gamut of data from the observations recorded at progressive stages of crop growth has been processed for statistical analysis to assess the essence of each treatment using $\mathrm{F}$-test as per the procedure suggested by Gomez and Gomez (1984). Least significance difference (LSD) values at $\mathrm{P}=$ 0.05 were used to determine the significant differences between treatment means. The interaction effects of different treatment combinations have been elaborated when they are significant.

\section{Results and Discussion}

As elaborated by Stoop et al., (2009), any comparison between two systems made up of several different crop management components is subject to compounding effects that will complicate and/ or interfere with the subsequent interpretation of the data. In this context, the results obtained in this experiment on SRI take on special significance as the effects of sets of recommended components have been evaluated.

\section{Studies on plant rice crop}

\section{Grain yield}

Early sowing (20 June) i.e. 15 days ahead of normal sowing was the most promising in recording significantly the highest grain yield of $5.811 \mathrm{t} \mathrm{ha}^{-1}$ that provided an additional yield of $0.333 \mathrm{t} \mathrm{ha}^{-1}(6.08 \%$ more) over 5 July sowing (Table 3). Sowing by 5 July had the advantage of producing significantly higher grain yield $\left(5.478 \mathrm{t} \mathrm{ha}^{-1}\right)$ than that of delayed sowing by 15 days causing saving of $0.663 \mathrm{t}$ $\mathrm{ha}^{-1}$ i.e. $13.77 \%$ yield. Thus there was reduction of grain yield to the tune of $0.0442 \mathrm{t}$ $\mathrm{ha}^{-1} \mathrm{~d}^{-1}$ due to delay in sowing time beyond 5 July. The lowest yield of $4.509 \mathrm{t} \mathrm{ha}^{-1}$ was in BMP on the contrary the highest yield of $6.108 \mathrm{t} \mathrm{ha}^{-1}$ was in MSRI while SRI produced moderate yield of $5.487 \mathrm{t} \mathrm{ha}^{-1}$ i.e. $0.621 \mathrm{t} \mathrm{ha}^{-1}$ (10.17\%) less than that of MSRI but $0.978 \mathrm{t}$ $\mathrm{ha}^{-1}(21.69 \%)$ more than in BMP. The hybrid rice Ajay produced $0.466 \mathrm{t} \mathrm{ha}^{-1}(9.07 \%)$ significantly higher grains than the high yielding variety Tapaswini.

\section{Economics of production}

An in-depth study on the economics of production of plant rice (Table 4) at varying dates of sowing indicated the highest gross return of Rs.86,854 and net return of Rs.41,510 ha $^{-1}$ with BCR of 1.92 and the lowest cost of production of Rs.6,822 $\mathrm{t}^{-1}$ of grain under early sowing by 20 June of hybrid rice Ajay in MSRI. The same genotype under same system of cultivation but under normal sowing on 5 July was second in order in recording gross return of Rs.86,335, net return of Rs.40,897 and BCR of 1.90. The variety Tapaswini under early sowing in MSRI was however third in rank to record net return of Rs.37,466 ha ${ }^{-1}$ and BCR of 1.85. The 
performance of rice variety Tapaswini under late sowing condition in BMP recorded the lowest gross return of Rs.46,423 and net return of only Rs.5,964 with BCR of 1.15 from the highest cost of production of Rs.11,529 $\mathrm{t}^{-1}$ of grains. The profitability of plant rice Ajay sown by 5 July under MSRI (Table 4) was of the highest with Rs.334 ha $\mathrm{d}^{-1}$. The profitability of the same genotype under same system of cultivation sown early by 20 June ranked second (Rs.316 ha ${ }^{-1} \mathrm{~d}^{-1}$ ) and cv. Tapaswini sown timely under MSRI (Rs.272 $\mathrm{ha}^{-1} \mathrm{~d}^{-1}$ ) followed the sequence.

However, the performance of cv. Tapaswini sown late by 20 July under BMP was poorest in the crop profitability (Rs. $48 \mathrm{ha}^{-1} \mathrm{~d}^{-1}$ ).

\section{Studies on ratoon rice crop}

\section{Grain yield}

The ratoon crop of 20 June sown rice produced significantly promising grain yield $\left(0.569 \mathrm{t} \mathrm{ha}^{-1}\right)$ compared to that of the grain yield in ratoon crop of 5 and 20 July sown rice which had grain yield within the limits of critical difference (Table 3). All three systems of cultivation i.e. BMP-ratoon, SRI-ratoon and MSRI-ratoon were significantly different in terms of their ratoon grain yield. The lowest yield of $0.463 \mathrm{t} \mathrm{ha}^{-1}$ was recorded in ratoon of BMP, whereas the highest yield of $0.603 \mathrm{tha}^{-1}$ was obtained in ratoon of MSRI and the moderate ratoon grain yield of $0.533 \mathrm{t} \mathrm{ha}^{-1}$ was recorded in SRI-ratoon. Hybrid rice Ajay $\left(0.542 \mathrm{t} \mathrm{ha}^{-1}\right)$ significantly out yielded Tapaswini $\left(0.524 \mathrm{t} \mathrm{ha}^{-1}\right)$ with statistical difference.

\section{Economics of production}

The economics of production of ratoon rice (Table 5) of plant rice sown at varying dates resulted in the highest gross return of Rs.8,794 $\mathrm{ha}^{-1}$ and net return of Rs.3,980 ha ${ }^{-1}$ with BCR of 1.83 under early sowing of Ajay in MSRI system with the lowest cost of production of Rs.7,453 $\mathrm{t}^{-1}$. Whereas it was interesting to find that ratoon crop of cv. Tapaswini under similar treatment combination was second in order in recording gross return of Rs.8,560. However, the net return (Rs.3,762) and BCR (1.82) were of second order in ratoon crop of plant rice Ajay sown by 5 July under MSRI. The performance of the stubble crop of $\mathrm{cv}$. Tapaswini under late sown condition in the system of BMP-ratoon recorded the lowest gross return of Rs.5,522 and net return of Rs.1,066 with BCR of 1.24. The cost of production was the highest (Rs.11,043 $\mathrm{t}^{-1}$ ) in this combination.

The data on the profitability of ratoon rice (Table 5) revealed that hybrid rice Ajay sown timely by 5 July under MSRI system was the best with value of Rs.69 $\mathrm{ha}^{-1} \mathrm{~d}^{-1}$ and same genotype under MSRI system sown early by 20 June ranked second (Rs.68 ha $\mathrm{h}^{-1}$ ). This was followed by the ratoon crop of plant rice cv. Tapaswini sown timely under MSRI system (Rs.66 ha ${ }^{-1} \mathrm{~d}^{-1}$ ) with respect to crop profitability. The performance of ratoon crop of plant rice cv. Tapaswini sown late by 20 July under BMP system was the lowest in order with crop profitability of only Rs. $22 \mathrm{ha}^{-1}$ $\mathrm{d}^{-1}$.

\section{Studies on green gram crop}

\section{Grain yield}

Early sowing of green gram by 2 January recorded significantly the highest seed yield of $0.703 \mathrm{tha}^{-1}$ and this was ensued by seeding by 17 January and 1 February, respectively with significant difference and in descending order (Table 3). Among the three systems of cultivation of rice, SRI-ratoon rice-green gram with significant difference had the advantage of recording the highest seed yield of green gram $\left(0.711 \mathrm{tha}^{-1}\right)$. 
Table.1 Irrigation water applied to rice-ratoon-green gram system as influenced by different treatments (pooled over 2009-10 and 2010-11)

\begin{tabular}{|c|c|c|c|c|}
\hline Treatments & $\begin{array}{l}\text { Plant rice } \\
\left(\mathrm{m}^{3} \mathbf{h a}^{-1}\right)\end{array}$ & $\begin{array}{l}\text { Ratoon } \\
\left(\mathrm{m}^{3} \mathbf{h a}^{-1}\right)\end{array}$ & $\begin{array}{c}\text { Green gram } \\
\qquad\left(\mathbf{m}^{3} \mathbf{h a}^{-1}\right)\end{array}$ & $\begin{array}{c}\text { System } \\
\left(\mathrm{m}^{3} \mathbf{h a}^{-1}\right)\end{array}$ \\
\hline \multicolumn{5}{|l|}{ Dates of sowing } \\
\hline 20 June (Pr) / 2 & $1501.3 \mathrm{c}$ & $1955.4 \mathrm{a}$ & 1500.0 & $4956.8 b^{*}$ \\
\hline 5 July (Pr) / 17 & $1808.9 b$ & $1699.0 \mathrm{c}$ & 1500.0 & $5008.0 \mathrm{~b}$ \\
\hline 20 July (Pr) /1 & $2226.2 \mathrm{a}$ & $1750.9 b$ & 1500.0 & $5477.1 \mathrm{a}$ \\
\hline C.D. (0.05) & 173.7 & 12.6 & 0 & 170.3 \\
\hline \multicolumn{5}{|l|}{ Systems of cultivation } \\
\hline BMP-ratoon-green & $3207.7 \mathrm{a}$ & 1753.3 & 1500.0 & $6461.0 \mathrm{a}$ \\
\hline SRI-ratoon-green & $931.4 \mathrm{c}$ & 1834.1 & 1500.0 & $4265.4 c$ \\
\hline MSRI-ratoon-green & $1397.4 b$ & 1818.0 & 1500.0 & $4715.4 b$ \\
\hline C.D. (0.05) & 307.1 & 32.9 & 0 & 309.3 \\
\hline \multicolumn{5}{|l|}{ Genotypes } \\
\hline Tapaswini & 2023.0 & 1805.7 & 1500.0 & $5328.7 \mathrm{a}$ \\
\hline Ajay & 1668.0 & 1797.9 & 1500.0 & $4965.8 b$ \\
\hline C.D. (0.05) & 40.8 & 9.1 & 0 & 42.5 \\
\hline
\end{tabular}

* Means followed by common letters did not differ significantly up to $5 \%$ level.

Table.2 Agronomic practices of plant rice

\begin{tabular}{l|l|}
\hline \multicolumn{1}{|c|}{ Practices } & \multicolumn{1}{|c|}{$\begin{array}{c}\text { Best management } \\
\text { practice (BMP) }\end{array}$} \\
\hline $\begin{array}{l}\text { Seedling age } \\
\text { at }\end{array}$ & $\begin{array}{l}25 \text { days old seedlings } \\
\text { from raised dry bed } \\
\text { transplanting } \\
\text { nursery }\end{array}$ \\
\hline $\begin{array}{l}\text { Plant spacing } \\
\text { and density }\end{array}$ & $\begin{array}{l}\text { Two seedlings per hill } \\
\text { at } 25 \text { cm } \mathrm{X} 12.5 \text { cm } \\
\text { spacing quickly after } \\
\text { uprooting }\end{array}$ \\
\hline Nutrient & $\begin{array}{l}\text { FYM at the rate of } 5 \mathrm{t} \\
\text { ha }{ }^{-1} \text { along with total } \\
\text { phosphorous (P) and } \\
1 / 3^{\text {rd }} \text { of the total } \\
\text { recommended dose } \\
\left(100: 50: 50 \mathrm{~kg} \text { ha }{ }^{-1} \text { of }\right. \\
\mathrm{N}_{2} \mathrm{P}_{5}: \mathrm{K}_{2} \mathrm{O} \text { ) of the } \\
\text { nitrogenous (N) and } \\
\text { potassic }(\mathrm{K}) \text { fertilizers } \\
\text { were applied before }\end{array}$
\end{tabular}

\section{System of Rice Intensification (SRI)}

10 days old seedlings from raised dry bed nursery

One seedling per hill at $25 \mathrm{~cm} \times 25 \mathrm{~cm}$ spacing quickly after uprooting after uprooting FYM at the rate of $15 \mathrm{t} \mathrm{ha}^{-1}$ along with total $\mathrm{P}$ and $1 / 4^{\text {th }}$ of the total $\left(50: 50: 50 \mathrm{~kg} \mathrm{ha}^{-1}\right.$ of $\left.\mathrm{N}: \mathrm{P}_{2} \mathrm{O}_{5}: \mathrm{K}_{2} \mathrm{O}\right)$ nitrogenous and potassic fertilizers were applied before final puddling. Rest of the $\mathrm{N}$ and $\mathrm{K}$ fertilizers were applied in three equal splits i.e. $1 / 4^{\text {th }}$ each at 25,40 and 70 DAS. The share of the $\mathrm{N}$ fertilizer from chemical source has been reduced to half of the recommended dose keeping in view its availability from the $10 \mathrm{t}$ extra FYM applied to 


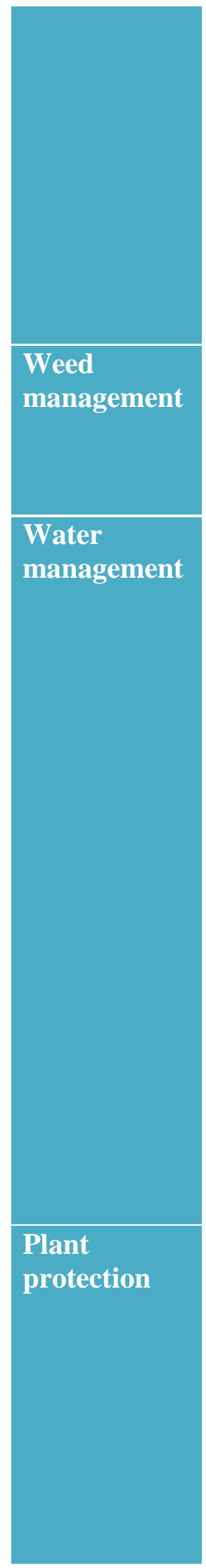

final puddling. Rest of the $\mathrm{N}$ and $\mathrm{K}$ fertilizers were applied in two equal halves i.e. $1 / 3^{\text {rd }}$ at maximum tillering i.e. 40 days after sowing (DAS) and $1 / 3^{\text {rd }}$ at panicle initiation (PI) stage (70 DAS).

Three hand weedings at 40, 55 and 70 DAS incorporating the weeds in situ.

Water was allowed to stand in the plots since planting of the seedlings by irrigating at alternate days so as to maintain a layer of 5 to $8 \mathrm{~cm}$ depth of water during the entire crop period till 15 days before harvest. the field at the time of final land preparation.

Four weedings at 20, Four weedings at 20, 30,40 and 50 DAS by 30,40 and 50 DAS cono-weeder in criss- by conoweeder in cross manner. east west direction only.

Water was not allowed to stand in the plots and special care was taken to avoid submergence of 10 days' old seedlings just after planting in the field. The soil was kept moist above the field capacity by irrigating the sub sub-plots as per requirement till PI. These plots were first irrigated 5 days after transplanting to moisten the field without ponding. A second irrigation was given on the evening of $9^{\text {th }}$ day after planting at a ponding depth of 2 to $5 \mathrm{~cm}$ and the next morning first weeding was performed by using conoweeder. Thereafter alternate wetting and drying irrigation method was practiced and subsequent irrigations were applied three days after disappearance of the ponded water or immediately after the development of hair cracks on the soil surface. However, after PI stage, the plots were allowed to hold standing water of $5 \mathrm{~cm}$ height up to two weeks before harvest.

Prophylactic sprays of neem oil at the rate of $5 \mathrm{~mL} \mathrm{~L}^{-1}$ of water at 15 days intervals were carried out to avoid any possible damage by insects and diseases. In addition, Trichocards with 1,00,000 viable eggs of Trichogramma japonicum ha $^{-1}$ were released at 15 days intervals i.e. at 40, 55 and 70 DAS for preventing the infestation by stem borers in all three systems of planting. Sex pheromone traps at the rate of 20 traps $^{-1}$ were installed and lures were regularly changed at 15 days intervals. However, necessary and adequate plant protection measures were adopted depending upon the possibility and incidence of the disease and pest infestation reached at economic threshold limit (ETL). 
Table.3 Effect of treatments on grain yield of plant rice, ratoon rice, green gram, rice equivalent yield (REY) green gram and rice-rtoon-green gram sytem and system productivity

\begin{tabular}{|c|c|c|c|c|c|c|}
\hline \multirow[t]{3}{*}{ Treatments } & \multicolumn{3}{|c|}{ Grain yield ( $\left.\mathrm{ha}^{-1}\right)$} & \multicolumn{2}{|c|}{ REY (t ha') } & \multirow{3}{*}{$\begin{array}{c}\text { System } \\
\text { productivity } \\
\left(\mathrm{kg} \mathrm{ha}^{-1} \text { day }^{-}\right. \\
\mathbf{1})\end{array}$} \\
\hline & \multicolumn{2}{|c|}{ Rice } & \multirow{2}{*}{$\begin{array}{c}\text { Green } \\
\text { gram }\end{array}$} & \multirow{2}{*}{$\begin{array}{l}\text { Green } \\
\text { gram }\end{array}$} & \multirow{2}{*}{ System } & \\
\hline & Plant & Ratoon & & & & \\
\hline \multicolumn{7}{|l|}{ Dates of sowing } \\
\hline 2 January & $5.811 \mathrm{a}$ & $0.569 a$ & $0.703 a$ & $2.933 a$ & $9.314 \mathrm{a}$ & $25.52 \mathrm{a}$ \\
\hline 17 January & $5.478 b$ & $0.524 b^{*}$ & $0.643 b$ & $2.571 b$ & $8.573 b$ & $23.49 b$ \\
\hline 1 February & $4.815 c$ & $0.505 b$ & $0.552 \mathrm{c}$ & $2.207 \mathrm{c}$ & $7.527 \mathrm{c}$ & $20.62 c$ \\
\hline C.D. (0.05) & 0.267 & 0.020 & 0.036 & 0.228 & 0.291 & 0.80 \\
\hline \multicolumn{7}{|l|}{ Systems of cultivation } \\
\hline BMP-ratoon-green gram & $4.509 c$ & $0.463 c$ & $0.516 \mathrm{c}$ & $2.065 b$ & $7.036 c$ & $19.28 \mathrm{c}$ \\
\hline SRI-ratoon-green gram & $5.487 \mathrm{~b}$ & $0.533 b$ & $0.711 \mathrm{a}$ & $2.844 \mathrm{a}$ & $8.864 b$ & $24.28 \mathrm{~b}$ \\
\hline MSRI-ratoon-green gram & $6.108 \mathrm{a}$ & $0.603 \mathrm{a}$ & $0.670 b$ & $2.803 a$ & $9.514 \mathrm{a}$ & $26.07 \mathrm{a}$ \\
\hline C.D. (0.05) & 0.232 & 0.021 & 0.031 & 0.257 & 0.319 & 0.87 \\
\hline \multicolumn{7}{|l|}{ Genotypes } \\
\hline Tapaswini & $5.135 b$ & $0.524 b$ & $0.641 \mathrm{a}$ & 2.645 & $8.304 b$ & $22.75 b$ \\
\hline Ajay & 5.601a & $0.542 \mathrm{a}$ & $0.624 b$ & 2.496 & $8.639 a$ & $23.67 \mathrm{a}$ \\
\hline C.D. (0.05) & 0.141 & 0.015 & 0.014 & NS & 0.230 & 0.63 \\
\hline
\end{tabular}

* Means followed by common letters did not differ significantly up to $5 \%$ level.

Table.4 Effect of treatments on economics of production of plant rice (Pooled over 2009 and 2010)

\begin{tabular}{|c|c|c|c|c|c|c|c|c|c|}
\hline Treatments & 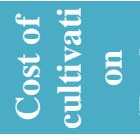 & 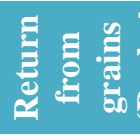 & 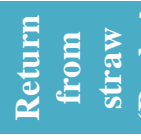 & 㔯言焉 & 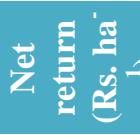 & 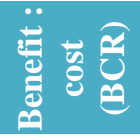 & 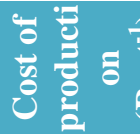 & 递总 & 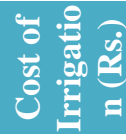 \\
\hline${ }^{1} \operatorname{Pr}\left(D_{1} S_{1} \mathbf{G}_{1}\right)$ & 40286 & 61508 & 2730 & 64238 & 23952 & 1.59 & 8187 & 170 & 1259 \\
\hline $\operatorname{Pr}\left(\mathbf{D}_{1} \mathbf{S}_{1} \mathbf{G}_{2}\right)$ & 42967 & 70029 & 3456 & 73486 & 30518 & 1.71 & 7669 & 227 & 1212 \\
\hline $\operatorname{Pr}\left(D_{1} \mathbf{S}_{2} \mathbf{G}_{1}\right)$ & 43237 & 70742 & 2992 & 73733 & 30496 & 1.71 & 7640 & 224 & 303 \\
\hline $\operatorname{Pr}\left(\mathbf{D}_{1} \mathbf{S}_{2} \mathbf{G}_{2}\right)$ & 43786 & 72121 & 3247 & 75368 & 31581 & 1.72 & 7589 & 244 & 291 \\
\hline $\operatorname{Pr}\left(D_{1} S_{3} G_{1}\right)$ & 44230 & 78371 & 3325 & 81696 & 37466 & 1.85 & 7055 & 272 & 499 \\
\hline $\operatorname{Pr}\left(D_{1} S_{3} G_{2}\right)$ & 45344 & 83079 & 3775 & 86854 & 41510 & 1.92 & 6822 & 316 & 489 \\
\hline $\operatorname{Pr}\left(D_{2} S_{1} G_{1}\right)$ & 40324 & 53454 & 2563 & 56017 & 15693 & 1.39 & 9430 & 117 & 1359 \\
\hline $\operatorname{Pr}\left(\mathrm{D}_{2} \mathrm{~S}_{1} \mathrm{G}_{2}\right)$ & 42979 & 58981 & 3108 & 62089 & 19110 & 1.44 & 9109 & 150 & 1286 \\
\hline $\operatorname{Pr}\left(D_{2} S_{2} G_{1}\right)$ & 43380 & 66675 & 2832 & 69507 & 26127 & 1.60 & 8133 & 205 & 507 \\
\hline $\operatorname{Pr}\left(\mathbf{D}_{2} \mathbf{S}_{2} \mathbf{G}_{2}\right)$ & 43938 & 73656 & 3196 & 76852 & 32914 & 1.75 & 7457 & 271 & 502 \\
\hline $\operatorname{Pr}\left(D_{2} S_{3} G_{1}\right)$ & 44339 & 75413 & 3690 & 79103 & 34763 & 1.78 & 7349 & 269 & 669 \\
\hline $\operatorname{Pr}\left(D_{2} S_{3} G_{2}\right)$ & 45438 & 82683 & 3652 & 86335 & 40897 & 1.90 & 6869 & 334 & 644 \\
\hline $\operatorname{Pr}\left(D_{3} S_{1} G_{1}\right)$ & 40459 & 43867 & 2556 & 46423 & 5964 & 1.15 & 11529 & 48 & 1870 \\
\hline $\operatorname{Pr}\left(\mathbf{D}_{3} \mathbf{S}_{1} \mathbf{G}_{2}\right)$ & 43222 & 50317 & 2667 & 52983 & 9761 & 1.23 & 10737 & 81 & 1903 \\
\hline $\operatorname{Pr}\left(\mathbf{D}_{3} \mathbf{S}_{\mathbf{2}} \mathbf{G}_{\mathbf{1}}\right)$ & 42857 & 60875 & 2687 & 63562 & 20704 & 1.48 & 8800 & 173 & 435 \\
\hline $\operatorname{Pr}\left(\mathbf{D}_{3} \mathbf{S}_{2} \mathbf{G}_{2}\right)$ & 43471 & 67471 & 2798 & 70269 & 26798 & 1.62 & 8054 & 234 & 423 \\
\hline $\operatorname{Pr}\left(\mathbf{D}_{3} \mathbf{S}_{3} \mathbf{G}_{1}\right)$ & 43995 & 66783 & 2985 & 69768 & 25774 & 1.59 & 8235 & 215 & 709 \\
\hline $\operatorname{Pr}\left(\mathrm{D}_{3} \mathrm{~S}_{3} \mathrm{G}_{2}\right)$ & 45132 & 71788 & 3412 & 75199 & 30067 & 1.67 & 7859 & 261 & 723 \\
\hline
\end{tabular}


Table.5 Effect of treatments on economics of production of ratoon rice (Pooled over 2009 and 2010)

\begin{tabular}{|c|c|c|c|c|c|c|c|c|c|}
\hline Treatments & 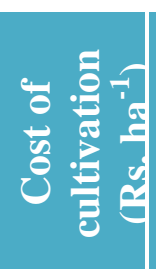 & 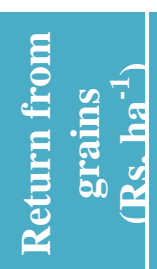 & 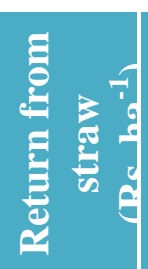 & 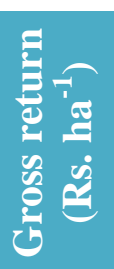 & 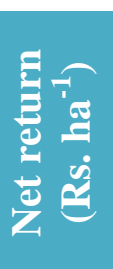 & 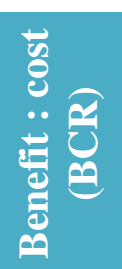 & 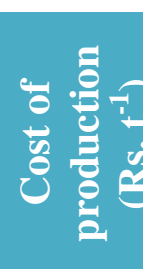 & $\begin{array}{l}0 \\
0 \\
0 \\
0 \\
0 \\
0 \\
0\end{array}$ & 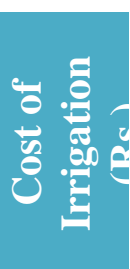 \\
\hline $\begin{array}{c}{ }^{1} \operatorname{Pr}\left(D_{1} S_{1} G_{1}\right)- \\
\mathbf{R r}\end{array}$ & 4703 & 6263 & 635 & 6898 & 2196 & 1.47 & 9385 & 37 & 988 \\
\hline $\begin{array}{c}\operatorname{Pr}\left(D_{1} S_{1} G_{2}\right)- \\
R r\end{array}$ & 4676 & 6542 & 643 & 7185 & 2509 & 1.54 & 8934 & 44 & 961 \\
\hline $\begin{array}{c}\operatorname{Pr}\left(\mathbf{D}_{1} \mathbf{S}_{2} \mathbf{G}_{1}\right)- \\
\mathbf{R r}\end{array}$ & 4768 & 6949 & 584 & 7533 & 2766 & 1.58 & 8576 & 47 & 989 \\
\hline $\begin{array}{c}\operatorname{Pr}\left(D_{1} \mathbf{S}_{2} \mathbf{G}_{2}\right)- \\
\operatorname{Rr}\end{array}$ & 4745 & 7024 & 629 & 7653 & 2907 & 1.61 & 8445 & 50 & 967 \\
\hline $\begin{array}{c}\operatorname{Pr}\left(D_{1} S_{3} G_{1}\right)- \\
\operatorname{Rr}\end{array}$ & 4833 & 7858 & 702 & 8560 & 3726 & 1.77 & 7689 & 63 & 991 \\
\hline $\begin{array}{c}\operatorname{Pr}\left(D_{1} S_{3} G_{2}\right)- \\
\operatorname{Rr}\end{array}$ & 4814 & 8073 & 720 & 8794 & 3980 & 1.83 & 7453 & 68 & 972 \\
\hline $\begin{array}{c}\operatorname{Pr}\left(\mathbf{D}_{2} \mathbf{S}_{1} \mathbf{G}_{1}\right)- \\
\mathbf{R r} \\
\end{array}$ & 4449 & 5561 & 527 & 6088 & 1640 & 1.37 & 10000 & 31 & 831 \\
\hline $\begin{array}{c}\operatorname{Pr}\left(\mathbf{D}_{2} \mathbf{S}_{1} \mathbf{G}_{2}\right)- \\
\operatorname{Rr}\end{array}$ & 4395 & 5327 & 509 & 5836 & 1441 & 1.33 & 10314 & 29 & 778 \\
\hline $\begin{array}{c}\operatorname{Pr}\left(D_{2} S_{2} G_{1}\right)- \\
\operatorname{Rr}\end{array}$ & 4579 & 6475 & 612 & 7087 & 2508 & 1.55 & 8840 & 45 & 897 \\
\hline $\begin{array}{c}\operatorname{Pr}\left(\mathbf{D}_{2} \mathbf{S}_{2} \mathbf{G}_{2}\right)- \\
\mathbf{R r}\end{array}$ & 4556 & 6835 & 601 & 7435 & 2879 & 1.63 & 8333 & 53 & 874 \\
\hline $\begin{array}{c}\operatorname{Pr}\left(\mathbf{D}_{2} \mathbf{S}_{3} \mathbf{G}_{1}\right)- \\
\mathbf{R r} \\
\end{array}$ & 4596 & 7457 & 644 & 8101 & 3505 & 1.76 & 7704 & 66 & 851 \\
\hline $\begin{array}{c}\operatorname{Pr}\left(D_{2} S_{3} G_{2}\right)- \\
\operatorname{Rr} \\
\end{array}$ & 4614 & 7640 & 735 & 8376 & 3762 & 1.82 & 7548 & 69 & 868 \\
\hline $\begin{array}{c}\operatorname{Pr}\left(D_{3} S_{1} G_{1}\right)- \\
\operatorname{Rr}\end{array}$ & 4456 & 5044 & 477 & 5522 & 1066 & 1.24 & 11043 & 22 & 838 \\
\hline $\begin{array}{c}\operatorname{Pr}\left(\mathbf{D}_{3} \mathbf{S}_{1} \mathbf{G}_{2}\right)- \\
\mathbf{R r}\end{array}$ & 4483 & 5957 & 573 & 6529 & 2046 & 1.46 & 9409 & 41 & 865 \\
\hline $\begin{array}{c}\operatorname{Pr}\left(\mathbf{D}_{\mathbf{3}} \mathbf{S}_{2} \mathbf{G}_{1}\right)- \\
\mathbf{R r} \\
\end{array}$ & 4550 & 6319 & 588 & 6907 & 2356 & 1.52 & 9001 & 47 & 868 \\
\hline $\begin{array}{c}\operatorname{Pr}\left(D_{3} \mathbf{S}_{2} G_{2}\right)- \\
\operatorname{Rr} \\
\end{array}$ & 4590 & 6360 & 586 & 6946 & 2356 & 1.51 & 9021 & 46 & 908 \\
\hline $\begin{array}{c}\operatorname{Pr}\left(D_{3} S_{3} G_{1}\right)- \\
\operatorname{Rr}\end{array}$ & 4620 & 7015 & 646 & 7661 & 3041 & 1.66 & 8233 & 61 & 874 \\
\hline $\begin{array}{c}\operatorname{Pr}\left(\mathbf{D}_{3} \mathbf{S}_{3} \mathbf{G}_{2}\right)- \\
\mathbf{R r}\end{array}$ & 4645 & 7161 & 678 & 7839 & 3194 & 1.69 & 8108 & 62 & 899 \\
\hline
\end{tabular}

\footnotetext{
${ }^{1}$ Pr-plant rice and Rr-ratoon rice
} 
Table.6 Effect of treatments on economics of production of green gram (Pooled over 2010 and 2011)

\begin{tabular}{|c|c|c|c|c|c|c|c|}
\hline Treatments & 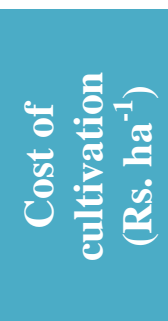 & 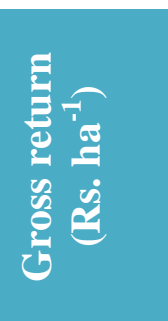 & 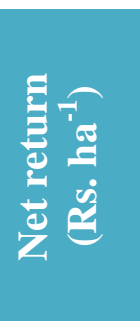 & 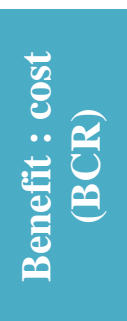 & 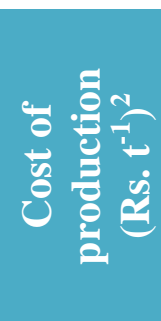 & 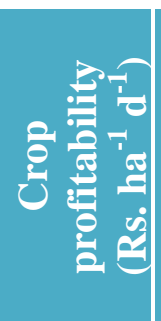 & 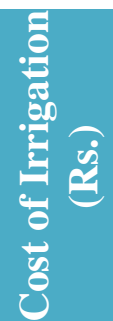 \\
\hline${ }^{1} \operatorname{Pr}\left(D_{1} S_{1} G_{1}\right)-R r-G g$ & 14581 & 28067 & 13485 & 1.92 & 25976 & 187 & 750 \\
\hline $\operatorname{Pr}\left(D_{1} S_{1} G_{2}\right)-R r-G g$ & 14581 & 28933 & 14352 & 1.98 & 25198 & 202 & 750 \\
\hline $\operatorname{Pr}\left(D_{1} S_{2} G_{1}\right)-\operatorname{Rr}-G g$ & 15027 & 40183 & 25157 & 2.67 & 18698 & 348 & 750 \\
\hline $\operatorname{Pr}\left(D_{1} S_{2} G_{2}\right)-\operatorname{Rr}-G g$ & 15027 & 38833 & 23807 & 2.58 & 19348 & 332 & 750 \\
\hline $\operatorname{Pr}\left(D_{1} S_{3} G_{1}\right)-R r-G g$ & 14963 & 37567 & 22603 & 2.51 & 19916 & 311 & 750 \\
\hline $\operatorname{Pr}\left(D_{1} S_{3} G_{2}\right)-\operatorname{Rr}-G g$ & 14963 & 37183 & 22220 & 2.48 & 20121 & 309 & 750 \\
\hline $\operatorname{Pr}\left(D_{2} S_{1} G_{1}\right)-R r-G g$ & 14263 & 26200 & 11937 & 1.84 & 27220 & 171 & 750 \\
\hline $\operatorname{Pr}\left(\mathrm{D}_{2} \mathrm{~S}_{1} \mathrm{G}_{2}\right)-\mathrm{Rr}-\mathrm{Gg}$ & 14263 & 24885 & 10621 & 1.74 & 28659 & 157 & 750 \\
\hline $\operatorname{Pr}\left(D_{2} \mathbf{S}_{2} G_{1}\right)-\operatorname{Rr}-\mathbf{G g}$ & 14709 & 38058 & 23349 & 2.59 & 19324 & 327 & 750 \\
\hline $\operatorname{Pr}\left(\mathrm{D}_{2} \mathrm{~S}_{2} \mathrm{G}_{2}\right)-\mathrm{Rr}-\mathrm{Gg}$ & 14709 & 36767 & 22058 & 2.50 & 20003 & 315 & 750 \\
\hline $\operatorname{Pr}\left(D_{2} S_{3} G_{1}\right)-R r-G g$ & 14645 & 33950 & 19305 & 2.32 & 21569 & 277 & 750 \\
\hline $\operatorname{Pr}\left(\mathrm{D}_{2} \mathrm{~S}_{3} \mathrm{G}_{2}\right)-\mathrm{Rr}-\mathrm{Gg}$ & 14645 & 32933 & 18288 & 2.25 & 22234 & 261 & 750 \\
\hline $\operatorname{Pr}\left(D_{3} S_{1} G_{1}\right)-\operatorname{Rr}-G g$ & 14009 & 25167 & 11158 & 1.80 & 27832 & 177 & 750 \\
\hline $\operatorname{Pr}\left(\mathrm{D}_{3} \mathrm{~S}_{1} \mathrm{G}_{2}\right)-\mathrm{Rr}-\mathrm{Gg}$ & 14009 & 21600 & 7591 & 1.54 & 32428 & 120 & 750 \\
\hline $\operatorname{Pr}\left(\mathrm{D}_{3} \mathrm{~S}_{2} \mathrm{G}_{1}\right)-\mathrm{Rr}-\mathrm{Gg}$ & 14454 & 28617 & 14163 & 1.98 & 25255 & 220 & 750 \\
\hline $\operatorname{Pr}\left(\mathrm{D}_{3} \mathrm{~S}_{2} \mathrm{G}_{2}\right)-\mathrm{Rr}-\mathrm{Gg}$ & 14454 & 30817 & 16363 & 2.13 & 23452 & 257 & 750 \\
\hline $\operatorname{Pr}\left(\mathrm{D}_{3} \mathrm{~S}_{3} \mathrm{G}_{1}\right)-\mathrm{Rr}-\mathrm{Gg}$ & 14391 & 30483 & 16093 & 2.12 & 23604 & 257 & 750 \\
\hline $\operatorname{Pr}\left(\mathrm{D}_{3} \mathrm{~S}_{3} \mathrm{G}_{2}\right)-\mathrm{Rr}-\mathrm{Gg}$ & 14391 & 28850 & 14459 & 2.00 & 24940 & 226 & 750 \\
\hline
\end{tabular}


Table.7 Effect of treatments on economics of production of plant rice (Pr)-ratoon rice ( $\mathrm{Rr})$-green gram (Gg) system gram (pooled over 2009-10 and 2010-11)

\begin{tabular}{|c|c|c|c|c|c|c|c|}
\hline Treatments & 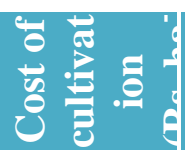 & 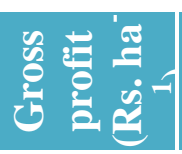 & 䒕送 & 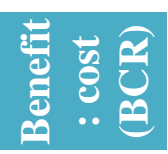 & 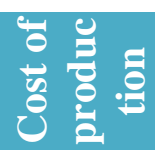 & 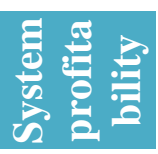 & 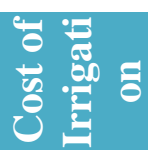 \\
\hline${ }^{1} \operatorname{Pr}\left(D_{1} S_{1} G_{1}\right)-R r-G g$ & 59570 & 99203 & 39633 & 1.67 & 7770 & 109 & 2997 \\
\hline $\operatorname{Pr}\left(D_{1} S_{1} G_{2}\right)-R r-G g$ & 62224 & 109604 & 47380 & 1.76 & 7372 & 130 & 2923 \\
\hline $\operatorname{Pr}\left(D_{1} S_{2} G_{1}\right)-R r-G g$ & 63032 & 121449 & 58417 & 1.93 & 6684 & 160 & 2042 \\
\hline $\operatorname{Pr}\left(D_{1} S_{2} G_{2}\right)-\operatorname{Rr}-G g$ & 63558 & 121854 & 58296 & 1.92 & 6734 & 160 & 2008 \\
\hline $\operatorname{Pr}\left(D_{1} S_{3} G_{1}\right)-\operatorname{Rr}-G g$ & 64026 & 127823 & 63797 & 2.00 & 6016 & 175 & 2240 \\
\hline $\operatorname{Pr}\left(D_{1} S_{3} G_{2}\right)-R r-G g$ & 65121 & 132831 & 67710 & 2.04 & 6343 & 186 & 2211 \\
\hline $\operatorname{Pr}\left(D_{2} S_{1} G_{1}\right)-R r-G g$ & 59036 & 88305 & 29269 & 1.50 & 8660 & 80 & 2940 \\
\hline $\operatorname{Pr}\left(D_{2} S_{1} G_{2}\right)-R r-G g$ & 61637 & 92810 & 31173 & 1.51 & 8638 & 85 & 2814 \\
\hline $\operatorname{Pr}\left(D_{2} S_{2} G_{1}\right)-R r-G g$ & 62668 & 114652 & 51984 & 1.83 & 7044 & 142 & 2154 \\
\hline $\operatorname{Pr}\left(D_{2} S_{2} G_{2}\right)-\operatorname{Rr}-G g$ & 63203 & 121054 & 57851 & 1.92 & 6738 & 158 & 2126 \\
\hline $\operatorname{Pr}\left(D_{2} S_{3} G_{1}\right)-\operatorname{Rr}-G g$ & 63580 & 121154 & 57574 & 1.91 & 6803 & 158 & 2270 \\
\hline $\operatorname{Pr}\left(\mathrm{D}_{2} \mathrm{~S}_{3} \mathrm{G}_{2}\right)-\mathrm{Rr}-\mathrm{Gg}$ & 64697 & 127644 & 62947 & 1.97 & 6561 & 172 & 2262 \\
\hline $\operatorname{Pr}\left(D_{3} S_{1} G_{1}\right)-R r-G g$ & 58924 & 77112 & 18188 & 1.31 & 9943 & 50 & 3458 \\
\hline $\operatorname{Pr}\left(D_{3} S_{1} G_{2}\right)-\operatorname{Rr}-G g$ & 61714 & 81112 & 19398 & 1.31 & 9906 & 53 & 3518 \\
\hline $\operatorname{Pr}\left(\mathrm{D}_{3} \mathrm{~S}_{2} \mathrm{G}_{1}\right)-\mathrm{Rr}-\mathrm{Gg}$ & 61861 & 99086 & 37225 & 1.60 & 8071 & 102 & 2053 \\
\hline $\operatorname{Pr}\left(\mathrm{D}_{3} \mathrm{~S}_{2} \mathrm{G}_{2}\right)-\mathrm{Rr}-\mathrm{Gg}$ & 62515 & 108032 & 45517 & 1.73 & 7467 & 125 & 2081 \\
\hline $\operatorname{Pr}\left(D_{3} S_{3} G_{1}\right)-\operatorname{Rr}-G g$ & 63006 & 107912 & 44906 & 1.71 & 7552 & 123 & 2333 \\
\hline $\operatorname{Pr}\left(D_{3} S_{3} G_{2}\right)-\operatorname{Rr}-G g$ & 64168 & 111888 & 47720 & 1.74 & 7441 & 131 & 2372 \\
\hline
\end{tabular}

${ }^{1}$ Pr-plant rice, $\mathrm{Rr}$-ratoon rice and Gr-green gram

${ }^{2}$ Cost of production was estimated by taking REY of rice-ratoon-green gram system

The effect of MSRI-ratoon rice-green gram on yield of green gram was moderate while BMP-ratoon rice-green gram significantly the lowest in green gram seed production. Both the genotypes of rice had significant effect on the seed yield of succeeding green gram crop. The yield of green gram grown in rice-ratoon sequence with Tapaswini out yielded Ajay with significant difference.

\section{Rice Equivalent Yield (REY)}

The seed yields of green gram were expressed as equivalent yields of rice grain yield (Table $3)$. The REY of green gram under early sowing by 2 January was significantly superior over the REY of 17 January and 1 February sown crops. REY of green gram grown after SRI-ratoon rice $\left(2.844 \mathrm{tha}^{-1}\right)$ was statistically at par with MSRI-ratoon $(2.803 \mathrm{t}$ $\mathrm{ha}^{-1}$ ) but both were significantly higher than in green gram in BMP-ratoon (2.065 $\left.\mathrm{t} \mathrm{ha}^{-1}\right)$ sequence. However, the REYs of green gram after rice-ratoon with both genotypes were statistically at par with each other.

\section{Economics of production}

The economics of production of green gram (Table 6) at varying dates of sowing resulted in the highest gross return of Rs.40,183 ha ${ }^{-1}$ and net return of Rs. $25,157 \mathrm{ha}^{-1}$ with BCR of 2.67 in the field where early sowing of cv. Tapaswini by 20 June in SRI was carried out. The gross return (Rs.38,833 ha ${ }^{-1}$ ) and net return (Rs.23,807 ha $\mathrm{ha}^{-1}$ ) of green gram crop 
under same condition but with change in genotype of the preceding rice by hybrid Ajay was second in order. However, the cost of production (Rs.19,916) was of higher degree in such a combination. The economics of production of green gram after cultivation of cv. Tapaswini under SRI-ratoon with timely sowing however was third in rank to record gross return of Rs.38,058 $\mathrm{ha}^{-1}$ and net return of Rs.23,349 ha-1 but the BCR of 2.59 was of second order. The performance of green gram sown after Ajay cultivated under late sown condition in BMP-ratoon recorded the lowest gross return of Rs. 21,600 ha $\mathrm{ha}^{-1}$ and net return of Rs.7,591 ha $\mathrm{ha}^{-1}$ with BCR of 1.54. However, the cost of production was the highest (Rs.32,428 $\mathrm{t}^{-1}$ ) in this combination.

The scrutiny of data on the profitability of green gram (Table 6) revealed that the green gram grown after ratoon crop of plant rice cv. Tapaswini sown early by 20 June under SRI recorded the highest crop profitability with Rs.348 ha ${ }^{-1} \mathrm{~d}^{-1}$. The profitability of the green gram after rice-ratoon with Ajay sown early under SRI was of second order (Rs.332 ha- $\mathrm{d}^{-}$ ${ }^{1}$ ) followed by the profitability of green gram grown after rice-ratoon with variety Tapaswini sown timely under SRI (Rs.327 ha $\left.{ }^{1} \mathrm{~d}^{-1}\right)$. The performance of green gram after rice-ratoon of hybrid Ajay sown late by 20 July under BMP was the lowest in crop profitability of Rs. $120 \mathrm{ha}^{-1} \mathrm{~d}^{-1}$.

\section{Studies on rice-ratoon-green gram system}

\section{Rice Equivalent Yield (REY)}

The REY from different crop components in the rice-ratoon-green gram system was calculated in a single commodity term i.e. rice grains (Table 3). Sowing of rice by 20 June followed by its ratooning and subsequently green gram sown by 2 January had significantly the highest REY of $9.314 \mathrm{t} \mathrm{ha}^{-1}$ followed by 5 July $\left(8.573 \mathrm{t} \mathrm{ha}^{-1}\right)$ and 20 July sowings $\left(7.527 \mathrm{t} \mathrm{ha}^{-1}\right)$ with statistical differences. The REY of MSRI-ratoon-green gram had top ranking (9.514 $\left.\mathrm{t} \mathrm{ha}^{-1}\right)$ followed by SRI-ratoon-green gram $\left(8.864 \mathrm{t} \mathrm{ha}^{-1}\right)$ with statistical difference from BMP-ratoon-green gram (7.036 $\left.\mathrm{t} \mathrm{ha}^{-1}\right)$. The hybrid rice Ajayratoon-green gram had significantly higher REY (8.639 $\mathrm{t} \mathrm{ha}^{-1}$ ) than with rice genotype Tapaswini-ratoon-green gram $\left(8.304 \mathrm{t} \mathrm{ha}^{-1}\right)$.

The system productivity (SP) calculated by dividing the REY of plant rice-ratoon-green gram by 365 clearly revealed that under early sown condition it was significantly superior $\left(25.52 \mathrm{~kg} \mathrm{ha}^{-1} \mathrm{~d}^{-1}\right)$ over both timely $(23.49 \mathrm{~kg}$ $\left.\mathrm{ha}^{-1} \mathrm{~d}^{-1}\right)$ and late $\left(20.62 \mathrm{~kg} \mathrm{ha}^{-1} \mathrm{~d}^{-1}\right)$ sown conditions with significant difference between them. The SP of MSRI-ratoon-green gram was significantly superior (26.07 $\mathrm{kg} \mathrm{ha}^{-1} \mathrm{~d}^{-1}$ ) over both SRI-ratoon-green gram $(24.28 \mathrm{~kg}$ $\left.\mathrm{ha}^{-1} \mathrm{~d}^{-1}\right)$ and BMP-ratoon-green gram (19.28 $\mathrm{kg} \mathrm{ha}^{-1} \mathrm{~d}^{-1}$ ) with statistical difference between them. The SP of rice-ratoon-green gram with hybrid rice Ajay (23.67 $\left.\mathrm{kg} \mathrm{ha}^{-1} \mathrm{~d}^{-1}\right)$ was significantly superior over the system with rice cv. Tapaswini $\left(22.75 \mathrm{~kg} \mathrm{ha}^{-1} \mathrm{~d}^{-1}\right)$.

\section{Economics of production}

The economics of production of rice-ratoongreen gram system (Table 7) at early sowing of Ajay in MSRI-ratoon-green gram resulted in the highest gross return of Rs.1,32,831 and net return of Rs.67,710 ha ${ }^{-1}$ with BCR of 2.04 from the second lowest cost of production of Rs.6,343 $\mathrm{t}^{-1}$ of paddy grains (REY) whereas cv. Tapaswini under same condition was of second order resulting in Rs.1,27,832 of gross profitability and cost of production of Rs.6,016 $\mathrm{t}^{-1}$ was the lowest (Table 5). However, it was interesting to note that the Ajay under MSRI-ratoon-green gram in normal sowing recorded gross return (Rs.1,27,644), net return (Rs.62,947) and BCR (1.97) of third order. In contrast, delayed sown condition of $\mathrm{cv}$. Tapaswini in 
BMP-ratoon-green green recorded the lowest gross return of Rs.77,112, net return of Rs.18,188 and BCR of 1.31 but the highest cost of production of Rs. $9,943 \mathrm{t}^{-1}$ in term of paddy grains due to substantial reduction in yield of rice and ratoon crop.

The system profitability of plant rice-ratoongreen gram as measured by summing up the net profits from plant rice, ratoon and green gram and divided by 365 days indicated that the highest profit (Rs.186 ha ${ }^{-1} \mathrm{~d}^{-1}$ ) was accrued from sowing of hybrid Ajay early by 20 June and green gram by 2 January under MSRI-ratoon-green gram system. Under similar treatment combinations the plant rice variety Tapaswini ranked second in this regard (Rs.175 ha ${ }^{-1} \mathrm{~d}^{-1}$ ). The hybrid rice Ajay under MSRI followed by its ratoon and succeeding green gram crop when sown in time recorded system profitability of third order (Rs.172 ha ${ }^{-1} \mathrm{~d}^{-1}$ ). However, the profitability was the least (Rs.50 ha- $\mathrm{d}^{-1}$ ) in the rice-ratoon-green gram system with cv. Tapaswini under BMP sown late by 20 July and green gram by 1 February.

Under the dwindling acreage of hybrid rice in Odisha early sowing of hybrid Ajay by 20 June under MSRI followed by ratoon and early sowing (2 January) of green gram in sequence should be given first priority so as to get maximum dividend in terms of net return, BCR and system profitability with minimum cost of production. The next best system giving all such benefits should be by taking HYV Tapaswini instead of hybrid Ajay under similar treatment combinations. However, preference for HYV Tapaswini under BMP sown late by 20 July and green gram by 1 February should be the least in rice-ratoon-green gram system in coastal plains of Odisha. These could be the recommendations to the farming communities of coastal Odisha as the better option for rice based cropping.

\section{Acknowledgements}

The technical and informative support of Visva Bharati, Santiniketan, West Bengal; National Rice Research Institute, Cuttack; Krishi Vigyan Kendra, Jagatsinghpur and College of Agriculture, Chiplima for conducting such Doctoral research of the first author are highly acknowledged.

\section{References}

Agriculture Department, Government of Odisha. Outcome Budget 2015-16, Pp.77.

Balamurugan, R. and Sudhakar, P. 2012. Influence of planting methods and different vermicompostis on yield and nitrogen use efficiency in rice. Iternational Journal of Current Agricultural Sciences, 2(6).

Bray, R. H., and Kurtz, L. T. 1945. Determination of total, organic and available forms of phosphorus in soils. Soil Science, 59: 39-45.

Chapagain, T., Riseman, A. and Yamaji, E. 2011. Achieving more with less water: Alternate wet and dry irrigation (AWDI) as an alternative to the conventional water management practices in rice farming. Journal of Agricultural Science, 3(3): 3-13.

Choudhury, B. U., Singh, A. K., Bouma, B. A. M. and Prasad, J. 2007. System of Rice Intensification and irrigated transplanted rice: Effect on crop water productivity. Journal of the Indian Society of Soil Science, 55(4): 464-470.

Cochran, G. and Cox, G. M. 1977. Experimental designs, P. S. Jaysingh, New York Asia publishing House, Ed; 218-219.

Daliri, M. S., Eftekhari, A., Mobasser, H. R., Ztari, D. B. and Porkalhor, H. 2009. Effect of cutting time and cutting height on yield and yield components of ratoon 
rice. (Tarom Langrodi Variety). Asian Journal of Plant Sciences, 8(1): 89-91.

Dass, A. and Chandra, S. 2012. Effect of different components of SRI on yield, quality, nutrient accumulation and economics of rice (Oryza sativa) in tarai belt of northern India. Indian Journal of Agronomy, 57(3): 250-254.

Dwibedi, S. K., De, G. C. and Dhua, S. R. 2016a. Energetics of rice-ratoon-green gram production system in coastal Odisha. International Journal of Agriculture Sciences, 8(9):1096-1099.

Dwibedi, S. K., De, G. C. and Dhua, S. R. 2016b. Influence of sowing time and system of cultivation of kharif (wet season) rice (Oryza sativa L.) genotypes on nutrient and water use efficiency in eastern coastal alluvial soil of India. International Journal of Agriculture Sciences, 8(51):2335-2340.

Gomez, K. A. and Gomez, A. A. 1984. Statistical procedures for agricultural research. Second edition. Wiley India, pp. 200-206.

Krupnik, T. J., Shennan, C. and Rodenburg, J. 2012. Yield, water productivity and nutrient balance under the system of rice intensification and recommended management practices in the Sahet. Field Crop Research, 130: 155-197.

Kumar, D. D. and Singh, A. P. 2013. Effect of integrated weed management on weed flora distribution, weed dynamics and performance of rice (Oryza sativa L.) under system of rice intensification (SRI) in Chhattisgarh. Journal of
Progressive Agriculture, 4(1): 96-101.

Lenka, D. 1976. Classification of rainfall zones and drought prone areas, (In) water management of crops in Orissa. Directorate of Agriculture, Government of Orissa, pp. 4-5.

Mobasser Hamid Reza; Siavoshi Morteza; Taari Davood Barari; Eftekhari Ali and Pourkalhor Hamid 2009. Determination of rice ratooning characteristics and yield as influenced by different agronomic practices. Indian Journal of Crop Science, 4(1 \& 2).

Oad, F. C. and Cruz, Pompe Sta. 2002. Rice varietal screening for ratoonability. Journal of Applied Sciences, 2(1).

Sato, S. and Uphoff, N. 2007. A review of onfarm evaluations of system of rice intensification methods in Eastern Indonesia. $C A B$ Reviews: Perspectives in Agriculture, Veterinary Science, Nutrition and Natural Resources, 2(54): $1-12$.

Shekhar, J., Mankotia, B. S. and Dev, S. P. 2009. Productivity and economics of rice (Oryza sativa) in system of rice intensification in North-Western Himalayas. Indian Journal of Agronomy, 54(4): 423-427.

Stoop, W. A., Adam, A., Kassam, A. 2009. Comparing rice production systems: a Challenge for agronomic research and for the dissemination of knowledge intensive farming practices. Agricultural Water Management, 96: 1491-1501.

\section{How to cite this article:}

Sanat Kumar Dwibedi, Gopal Chandra De, Sudhi Ranjan Dhua, Biswa Ranjan Pattanaik, Bijaya Kumar Sethy and Sasmita Priyadarshini. 2018. Comparative Economics of RiceRatoon-Green gram Production System in East and South East Coastal Plain Zone of Odisha, India. Int.J.Curr.Microbiol.App.Sci. 7(02): 2247-2261.

doi: https://doi.org/10.20546/ijcmas.2018.702.271 